\title{
Gel ekstrak daun meniran (Phyllanthus niruri) meningkatkan epitelisasi penyembuhan luka pada kulit tikus putih jantan galur Wistar (Rattus norvegicus)
}

\author{
${ }^{1}$ Marintan S. Y. Siahaan \\ ${ }^{2}$ Wimpie Pangkahila \\ ${ }^{3}$ IGM Aman \\ ${ }^{1}$ Program Pascasarjana Anti-Aging Medicine \\ ${ }^{2}$ Departemen Pasca Sarjana Anti-Aging Medicine \\ ${ }^{3}$ Departemen Farmakologi \\ Fakultas Kedokteran Universitas Udayana Denpasar \\ Email: piensiahaan@gmail.com
}

\begin{abstract}
Skin wound can cause bleeding, bacterial contamination, sympathetic stress response, and cell death. Aging of the skin slowens and delays the regeneration process of the wound bed. Meniran leaf (Phyllanthus niruri) contains several bioactive molecules and antimicrobial effects that improve the wound healing. This study was aimed to prove that meniran leaf extract gel could increase epithelization of wound in Wistar male rats. This was an experimental study. Subjects were 36 Wistar rats (Rattus norvegicus) adult, healthy, aged 3-3.5 months, weighing 200-250 g, divided into 2 groups, the control group and the treatment group; each of 18 rats. The control group (P0) was given placebo gel and oral amoxicillin for 8 days. The treatment group (P1) was given $20 \%$ meniran leaf extract gel and oral amoxicillin for 8 days. Slides of skin tissue were stained with HE. Microscopically, epithelial thickness were evaluated at three different points per field of view with $10 \mathrm{x}$ objective magnification The results showed that the average epithelization in P0 group was $48.28 \pm 20.72 \mu \mathrm{m}$, meanwhile in $\mathrm{P} 1$ group was $63.79 \pm 18.37 \mu \mathrm{m}(P<0.001)$. Conclusion: Application of $20 \%$ meniran leaf extract gel could increase epithlization of wound bed in male Wistar rats.
\end{abstract}

Keywords: meniran leaf, epithelization, wound

\begin{abstract}
Abstrak: Luka pada kulit mengakibatkan timbulnya perdarahan, kontaminasi bakteri, respon stres simpatis, bahkan kemungkinan terburuk yaitu kematian sel. Penuaan pada kulit akan memperlambat dan menghambat proses regenerasi jaringan luka. Daun meniran (Phyllanthus niruri) mengandung molekul bioaktif yang berefek pada penyembuhan luka dan antimikroba. Penelitian ini bertujuan untuk membuktikan bahwa pemberian gel ekstrak daun meniran meningkatkan epitelisasi jaringan luka pada tikus putih Wistar jantan. Jenis penelitian ialah eksperimental. Subyek penelitian ialah 36 ekor tikus galur Wistar (Rattus norvegicus) dewasa dan sehat, berumur 3-3,5 bulan, dengan berat badan 200-250 gram, yang dibagi menjadi 2 kelompok yaitu kelompok kontrol dan perlakuan; masing-masing berjumlah 18 ekor tikus. Kelompok kontrol (P0) diberikan gel plasebo dan amoxicillin oral selama 8 hari. Kelompok perlakuan (P1) diberikan gel ekstrak daun meniran konsentrasi $20 \%$ dan amoxicillin oral selama 8 hari. Jaringan kulit dibuat preparat yang diwarnai dengan HE. Pada pengamatan mikroskopik dengan pembesaran lensa objektif 10x diukur ketebalan epitel di tiga titik berbeda dalam satu lapang pandang. Hasil penelitian menunjukkan rerata epitelisasi pada kelompok P0 ialah $48,28 \pm 20,72 \mu \mathrm{m}$, sedangkan pada kelompok P1 ialah $63,79 \pm 18,37 \mu \mathrm{m}(P<0,001)$. Simpulan: Pemberian gel ekstrak daun meniran (Phyllanthus niruri) dapat meningkatkan epitelisasi jaringan luka pada kulit tikus Wistar jantan.
\end{abstract}

Kata kunci: daun meniran, epitelisasi, luka 
Penuaan adalah suatu proses alami yang pasti terjadi pada semua mahkluk hidup. Terdapat beberapa faktor yang menyebabkan orang menjadi tua, yaitu faktor internal dan faktor eksternal. Yang termasuk dalam faktor internal ialah radikal bebas, berkurangnya hormon, proses glikolisasi, metilasi, apoptosis, menurunnya sistem kekebalan, dan genetik sedangkan faktor eksternal yang utama ialah gaya hidup tidak sehat, kebiasaan salah, polusi lingkungan, stres, dan kemiskinan. ${ }^{1}$

Seiring bertambahnya usia, terjadi penurunan fungsi fisiologis berbagai jenis organ dan jaringan dalam tubuh, salah satunya ialah kulit. Lapisan kulit terdiri dari 3 lapisan yaitu epidermis, dermis, dan subkutan. Epidermis merupakan lapisan yang terutama mengalami penuaan seiring dengan bertambahnya usia. Pertambahan usia menyebabkan beberapa fungsi kulit manusia menurun seperti penyembuhan luka, fungsi barier, pergantian sel, pembersihan zat kimia, persepsi sensoris, mekanisme proteksi, respon imun, termoregulasi, produksi keringat, produksi sebum, produksi vitamin $\mathrm{D}$, dan perbaikan DNA. $^{2}$

Terdapat beberapa definisi luka yaitu hilang atau rusaknya sebagian dari jaringan tubuh, serta kerusakan fisik akibat dari terbukanya atau hancurnya kulit yang menyebabkan ketidakseimbangan fungsi dan anatomi kulit normal. ${ }^{3}$

Mekanisme penyembuhan luka terdiri dari 3 fase, yaitu: fase inflamasi (0-3 hari), fase proliferasi (3-14 hari), dan fase remodeling jaringan (bisa dimulai pada hari ke 8 dan berlangsung sampai 1 tahun). Proses penyembuhan luka tersebut merupakan suatu hal kompleks yang melibatkan interaksi yang terus menerus antara sel dan sel serta antara sel dan matriks. ${ }^{4}$

Hasil penyembuhan luka tergantung dari perluasan dan kedalaman luka, serta ada tidaknya komplikasi yang mengganggu perjalanan proses penyembuhan luka yang alami. Gangguan tersebut menyebabkan proses penyembuhan luka yang lama, seperti pada orang berusia lanjut, pengobatan dengan steroid, diabetes melitus, dan kanker yang dapat menyebabkan infeksi lebih meningkat. ${ }^{5}$

Penyembuhan luka merupakan suatu proses biologik yang dimulai dari adanya trauma sampai dengan terbentuknya luka parut. Tujuan dari pengelolaan luka yang lebih baik ialah penyembuhan luka dalam waktu sesingkat mungkin, dengan rasa sakit, ketidaknyamanan, dan luka parut yang minimal pada pasien, ${ }^{6}$ meminimalkan kerusakan jaringan, penyediaan perfusi jaringan yang cukup dan oksigenasi, nutrisi yang tepat untuk jaringan luka, ${ }^{7}$ mengurangi faktor-faktor risiko yang dapat menghambat penyembuhan luka, mempercepat proses penyembuhan dan menurunkan kejadian luka terinfeksi. ${ }^{6}$

Terdapat banyak substansi yang dapat mempercepat penyembuhan luka diantaranya beberapa ekstrak tanaman walaupun sebenarnya penggunaan tersebut merupakan kebiasaan yang dilakukan oleh masyarakat tradisional. ${ }^{8}$ Sekitar $25 \%$ dari pengobatan di negara berkembang menggunakan tanaman obat yang sebelumnya melalui proses trial and error. ${ }^{6}$ Tanaman obat yang biasa dipakai untuk mempercepat penyembuhan luka, diantaranya ialah tanaman herbal meniran. ${ }^{9}$ Meniran (Phyllanthus niruri) merupakan famili Euphorbiaceae yaitu semacam tanaman liar berasal dari Asia tropik yang tersebar di seluruh daratan Asia dan sangat mudah ditemui di Indonesia. ${ }^{10}$ Pada uji analisis ekstrak meniran yang dilakukan di Unit Laboratorium Fakultas Teknologi Pertanian Universitas Udayana pada bulan Juni 2016 didapatkan hasil sebagai berikut: flavonoid 677,27 mg/100gr QE; fenol 1972,21 mg/100gr GAE; tanin 14045,48 $\mathrm{mg} / 100 \mathrm{gr}$ TAE, vitamin C 9506,69 mg/100gr, dan kapasitas antioksidan 118038,52 mg/L GAEAC. Pada bulan Agustus 2016 dilakukan lagi uji analisis ekstrak meniran di Unit Layanan Analisis Sampel Fakultas MIPA Universitas Udayana Kampus Bukit Jimbaran dan didapatkan antioksidan pada meniran antara lain saponin dan sterol atau steroid alkohol yang merupakan anti-oksidan yang berperan penting pada kontraksi luka dan 
dapat meningkatkan epitelisasi. ${ }^{6}$

\section{METODE PENELITIAN}

Jenis penelitian ini ialah eksperimental dengan menggunakan completely randomized post-test only control group design. Subjek yang digunakan ialah 36 ekor tikus galur Wistar (Rattus norvegicus) dewasa dan sehat, usia 3-3,5 bulan, dengan berat badan 200-250 gr, dibagi menjadi 2 kelompok; masing-masing berjumlah 18 ekor tikus. Kelompok pertama ialah kelompok kontrol (P0), diberikan gel plasebo dan amoxicillin oral selama 8 hari sedangkan kelompok kedua ialah kelompok perlakuan (P1), diberikan gel ekstrak daun meniran (Phyllanthus niruri) konsentrasi $20 \%$ dan amoxicillin oral selama 8 hari. Pemeriksaan histologik dilakukan pada hari ke 8 dengan mengambil jaringan luka untuk melihat epitelisasi jaringan dengan menggunakan pewarnaan hematokslin eosin. Data hasil penelitian dianalisis menggunakan software SPSS untuk uji parametrik $t$-independent karena data berdistribusi normal dan varian homogen.

\section{HASIL DAN BAHASAN}

Hasil penelitian menunjukkan rerata epitelisasi yang digambarkan dengan ketebalan lapisan epitel pada kelompok kontrol (P0) setelah diberikan gel plasebo dan amoxicillin oral selama 8 hari ialah $48,28 \pm 20,72 \mu \mathrm{m}$, sedangkan pada kelompok perlakuan (P1) ialah 63,79 $\pm 18,37 \mu \mathrm{m} \quad(P \quad<0,05) \quad$ (Tabel 1; Gambar 1).

Tabel 1. Komparasi rerata epitelisasi antar kelompok

\begin{tabular}{lcccc}
\hline \multicolumn{1}{c}{ Kelompok subjek } & N & Rerata $(\boldsymbol{\mu m})$ & $\boldsymbol{t}$ & $\boldsymbol{P}$ \\
\hline Kelompok kontrol (P0) & 18 & $48,28 \pm 20,72$ & $-2,377$ & 0,023 \\
Kelompok perlakuan (P1) & 18 & $63,79 \pm 18,37$ & & \\
\hline
\end{tabular}

$t=t$-test, $P=$ signifikansi

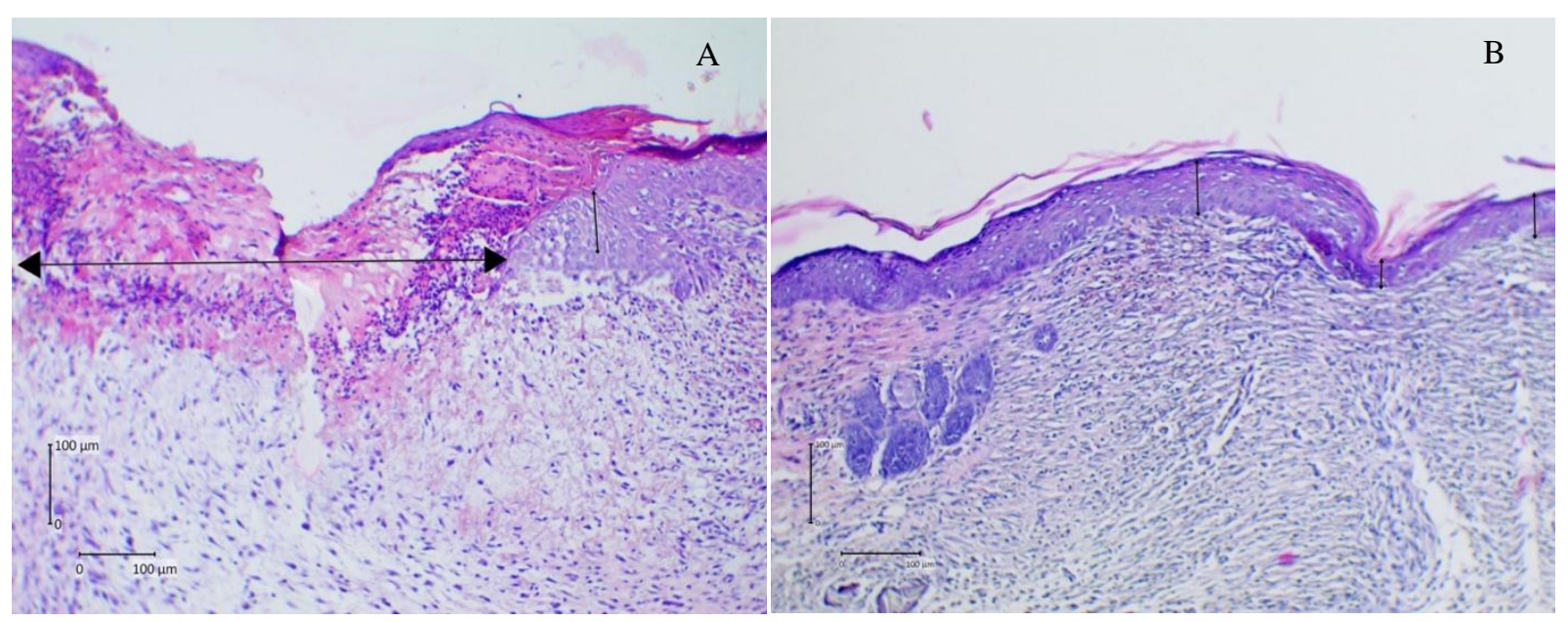

Gambar 1. Histopatologi jaringan kulit. A) Kelompok kontrol (P0); B) Kelompok perlakuan (P1)

Hasil penelitian ini didukung oleh hasil penelitian terdahulu. Ahmed et al. ${ }^{11}$ menunjukkan bahwa pada kelompok tikus yang diinduksi luka dan diberikan ekstrak daun meniran (Phyllanthus niruri) 5\% dan $10 \%$ dapat mengurangi lebar bekas luka, meningkatkan proliferasi fibroblas, serta meningkatkan jumlah kolagen dan angiogenesis dibandingkan dengan kelompok diberikan plasebo. Penelitian lain juga membuktikan bahwa ekstrak daun meniran dapat mempercepat penyembuhan luka 
karena melindungi jaringan kulit dari kerusakan oksidatif akibat radikal bebas. ${ }^{12}$ Selain itu Shanbag et al. ${ }^{13}$ membuktikan bahwa pemberian ekstrak daun meniran baik secara oral maupun topikal dapat mempercepat proses penyembuhan luka bakar yang ditandai dengan lebih cepatnya periode epitelisasi.

Hasil penelitian ini terkait kandungan senyawa aktif pada ekstrak daun meniran. Berdasarkan hasil uji analisis fitokimia ekstrak daun meniran (Phyllanthus niruri) yang dilakukan di Unit Laboratorium Fakultas Teknologi Pertanian Universitas Udayana pada bulan Juni 2016 didapatkan bahwa ekstrak ini mengandung berbagai antioksidan dengan aktivitas antioksidan sebesar 118038,52 mg/L GAEAC. Selain itu uji analiis ekstrak meniran di Unit Layanan Analisis Sampel Fakultas MIPA Universitas Udayana kampus bukit Jimbaran mendapatkan antioksidan pada meniran antara lain saponin.

Kandungan flavonoid pada tumbuhan herbal telah banyak dibuktikan dapat mempercepat penyembuhan luka dengan meningkatkan proses epitelisasi yang merupakan proses pembaharuan epitel setelah terjadinya luka, yang melibatkan proliferasi dan migrasi sel epitel menuju pusat luka dan kontraksi luka disebabkan oleh aksi miofibroblas. ${ }^{14}$ Flavonoid telah dibuktikan dapat meningkatkan migrasi dan proliferasi sel epitel, serta meningkatkan migrasi dan aktivitas miofibroblas. ${ }^{15}$ Pemberian flavonoid oral dapat meningkatkan epitelisasi dan pembentukan jaringan granuloma pada luka. Peningkatan epitelisasi dan jaringan granuloma pada luka dapat terjadi karena peningkatan produksi kolagen dan angiogenesis pada luka. ${ }^{16-18}$ Proses ini merupakan indikator dari proses penyembuhan luka dan menunjukkan bahwa flavonoid dapat merangsang mekanisme yang terkait dengan penyembuhan luka dan regenerasi jaringan. Studi yang dilakukan Muralidhar et al. ${ }^{15}$ menunjukkan bahwa flavonoid secara bermakna dapat mempercepat proses penyembuhan luka dengan meningkatnya laju kontraksi luka, pemendekan periode epitelisasi, peningkatan deposisi kolagen, dan terbentuknya jaringan granulasi.

Selain flavonoid, ekstrak daun meniran juga mengandung senyawa aktif lain seperti fenol, tanin, serta saponin dan sterol. Senyawa aktif ini berperan sebagai antioksidan yang berpengaruh pada kontraksi luka dan meningkatkan kecepatan epitelisasi. ${ }^{6,19-21}$ Hal ini dipertegas dengan hasil pemeriksaan aktivitas antioksidan pada ekstrak daun meniran (Phyllanthus niruri) yang menunjukkan aktivitas antioksidan yang cukup tinggi yaitu sebesar $118038,52 \mathrm{mg} / \mathrm{L}$ GAEAC. Aktivitas antioksidan yang tinggi ini dapat mempercepat penyembuhan luka karena dapat menstimulasi produksi antioksidan endogen pada situs luka dan menyediakan lingkungan yang kondusif untuk terjadinya penyembuhan luka. ${ }^{11}$

\section{SIMPULAN}

Berdasarkan hasil penelitian ini dapat disimpulkan bahwa pemberian gel ekstrak daun meniran (Phyllanthus niruri) meningkatkan epitelisasi jaringan luka pada tikus wistar jantan.

\section{DAFTAR PUSTAKA}

1. Pangkahila W. Anti-aging Tetap Muda dan Sehat. Jakarta: PT Kompas Media Nusantara, 2011; p. 11-43.

2. Farage MA, Miller KW, Elsner P, Maibach

HI. Characteristics of the aging skin. Adv Wound Care. 2013;2(1):5-10. Doi:10.1089/wound.2011.0356.

3. Nagori BP, Solanki R. Role of medicinal plants in wound healing. Res $\mathrm{J}$ Med Plant. 2011;5 (4):392-405.

4. Broughton II G, Janis, JE, Attiger CE. Wound healing: an overview. Plast Reconstr Surg. 2006;117(suppl):1eS$32 \mathrm{eS}$.

5. Gurtner GC. Wound Healing: Normal and Abnormal. In: Thome $\mathrm{CH}$, editor. Grabb dan Smith's Plastic Surgery (6th ed). Philadelphia: Lippincott Williams \& Wilkins, 2007; p. 15-22.

6. Soni H, Singhai AK. A recent update of botanicals for wound healing activity. Int Res J Pharm. 2012;3:1-6.

7. Reddy GAK, Priyanka B, Saranya ChS, 
Kumar CKA. Wound healing potential of Indian medicinal plants. Int J Pharm Rev Res. 2012;2:75-8.

8. Mathivanan N, Surendiran G, Srinivasan K, Malarvizhi K. Morinda pubescens JE Smith (Morinda tinctoria Roxb.) Fruit extract accelerates wound healing in rats. J Med Food. 2006;4:591-3.

9. Meniran: Phylanthus niruri L., Acuan Sediaan Herbal Volume Kelima, Jakarta: Badan Pengawas Obat dan Makanan, 2010; p 54-8.

10. Dalimartha, S. Atlas Tumbuhan Obat Indonesia Jilid 4. Jakarta: Puspa Swara, 2000; p. 56-8.

11. Ahmed KA, Abdulla MA, Mahmoud FM. Wound healing potential of Phyllanthus niruri leaf extract in experimental rats. Mid-East J Sci Res. 2012;11(11): 16148.

12. Kurahasi T, Fujii J. Roles of antioxidative enzymes in wound healing. J Dev Biol. 2015;3:57-70.

13. Shanbhag T, Amuthan A, Shenoy S, Sudhakar. Effect of Phyllanthus niruri Linn. on burn wound in rats. Asian Pac J Trop Med. 2010;3(2):105-8.

14. Mohan H. Inflammation and healing, In: Textbook of Pathology (5th ed). New Delhi: Jaypee Brothers, 2005; p. 13379. ISBN:81-8061-368-2.

15. Muralidhar A, Babu KS, Sankar TR, Reddanna P, Latha J. Wound healing activity of flavonoid fraction isolated from the stem bark of Butea monosperma (Lam) in albino wistar rats. Eur J Exp Biol. 2013;3(6):1-6.

16. Bairy KL, Rao CM. Wound healing profiles of Ginkgo biloba. J Nat Remedies. 2001;1:25-7.

17. Swamy KH, Krishna V, Shankarmurthy K, Rahiman AB, Mankani KL, Mahadevan KM. Wound healing activity of embelin isolated from the ethanol extract of leaves of Embelia ribes Burm. J Ethnopharmacol. 2007; 109:529-34.

18. Harish BG, Krishna V, Kumar HS, Ahamed KB, Sharath R, Swamy KH. Wound healing activity and docking of glycogen-synthase-kinase- 3 - $\beta$-protein with isolated triterpenoid lupeol in rats. Phytomedicine. 2008; 15:763-7.

19. Chaudhari M, Mengi S. Evaluation of phytoconstituents of Terminalia arjuna for wound healing activity in rats. Phytother Res. 2006;20(9):799-805.

20. Karodi R, Jadhav M, Rub R, Bafna A. Evaluation of the wound healing activity of a crude extract of Rubia cordifolia L. (Indian madder) in mice. Int J Appl Res Nat Prod. 2009;2(2):128.

21. Thakur R, Jain N, Pathak R, Sandhu SS. 2011. Practices in wound healing studies of plants. Evidence-based eCAM. 2011;2011:438056. Doi:10.1155/2011/438056. 